\title{
A SHORT SYNTHESIS FOR THE PREPARATION OF POLYCYCLIC SYSTEMS CONTAINING PYRIDINE RING BY DIELS-ALDER REACTION
}

\author{
Consol Bozzo and M.Dolors Pujol* \\ Laboratori de Química Farmaceutica, Facultat de Farmàcia, Universitat de Barcelona, \\ Av. Diagonal 643, 08028 Barcelona, Spain \\ Fax (3) 40218 86, E-mail mdpujol@farmacia.far.ub.es
}

\begin{abstract}
The fused heterocycles with pyridine ring are synthesized in two steps from the appropriate isobenzofuran. The dienes 2 and 3 undergo Diels-Alder reaction with 3,4-pyridyne, generated in situ from 3bromopyridine, to give the expected adducts in good yields. Reduction of these adducts with $\mathrm{LiAlH}_{4}$ in ether gives the aromatic compounds. The intermediates obtained are versatile building blocks for synthesis in organic chemistry.
\end{abstract}

\section{Introduction}

The heterocycles with fused pyridine ring are of particular interest due to its properties as a pharmacophore of several biologically active polycyclic aromatic compounds (1-2). The synthesis of numerous and diversified polycyclic systems may be easily performed by cyclo-addition reactions (3).

A large variety of dienes and dienophiles, bearing a variety of functional groups, can be used, and several different types of ring structures build up. For the preparation of pyridine analogues the protected $\delta$ valerolactam (4) or the 3,4-dehydropyridine (3,4-pyridyne) are the best intermediates used as dienophiles. In this way, the 3,4-pyridyne could be generated: a) from dihalopyridines [3-chloro-4-iodopyridine (5-7)] and trapped in a Diels-Alder reaction; b) from a monohalopyridine [3-chloro or 3-bromopyridine (8-9)] by a strong base; or c) from pyridine derivatives: many of these products are not available and must be synthesized [1aminotriazolo[4,5-c]pyridine (10), 3-(3,3-dimethyltriazen-1-yl)pyridine-4-carboxylic acid (11), 3-diazopyridine4-carboxylic acid (12) or 4-trialkylsilyl-3-pyridyl triflates (13)]

In general, the cycloadduct of the Diels-Alder condensation with 3,4-pyridyne is obtained in low yield (6-13) in comparison with the benzene analogues. The results could be attributable to diene, to pyridyne formation or to reaction conditions. From the viewpoint of availability of starting materials the most interesting procedure for generating pyridyne is the base-induced dehydrohalogenation of 3-halopyridines. In this case, according to the bibliography, the best yield of a cycloaddition reaction is lower than $40 \%$ (14). 


\section{Chemistry and discussion}

We now report new conditions for the dehydrohalogenation of 3-bromopyridine and condensation with the appropriate isobenzofuran; our approach is indicated in scheme 1 .
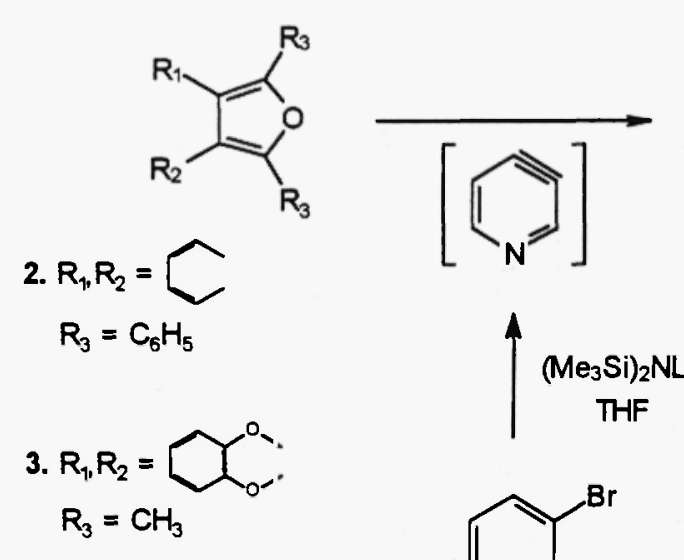<smiles>[R]C1=C([R])C([R])(O)C2([R])OC1([R])c1cnccc12</smiles>

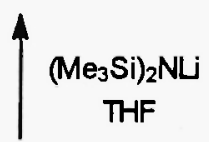
4. $R_{1}, R_{2}=\widetilde{C}$ $\mathrm{R}_{3}=\mathrm{C}_{6} \mathrm{H}_{5}$<smiles>Brc1cccnc1</smiles>
5. $R_{1}, R_{2}=Y_{0}^{2}$ $\mathrm{R}_{3}=\mathrm{CH}_{3}$

\section{Scheme 1}

The 3,4-pyridyne was generated from 3-bromopyridine by treatment with lithium bis(trimethylsilyl)amide [( $\left.\left(\mathrm{Me}_{3} \mathrm{Si}\right)_{2} \mathrm{NLi}\right]$ in THF at a temperature below $-15^{\circ} \mathrm{C}$, and it was captured by the isobenzofuran 2 affording the desired compound 4 in $64 \%$ yield, after $20 \mathrm{~h}$ at reflux of THF and purification by chromatography on silica gel. As a result, the adduct of the cycloaddition was obtained in good yield in comparison with the results described thus far. The methodology was applied to the diene 3, obtained from the 1,4-benzodioxin-2-carboxylic acid in four steps (15). We were surprised to find that treatment of 3 gave only $20 \%$ yield of the adduct 5 ; the low yield is due in particular to the formation of the dimer $6(14 \%)$ containing the pyridine subunit (Scheme 2). The optimisation of this yield is in progress, and we have detected now the unstability of the adduct 5<smiles>[X]C12Oc3ccccc3OC1(C)c1ccncc12</smiles><smiles>[Z]=[Z]1ccc2c(c1)OC(C(C)(C)C)=C(C(C)(C)C)O2</smiles>

Scheme 2

Our initial goal was the synthesis of aromatic compounds. For this reason we attempted the deoxygenation of 4 with several methods (Scheme 3). 


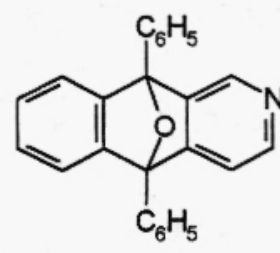

4<smiles></smiles>

7

Scheme 3

The initial attempts of reduction of 4 (entries 1-5 in table 1) with $\mathrm{Fe}_{2}(\mathrm{CO})_{9}$ in benzene (16), $\mathrm{NaBH}_{4} / \mathrm{NaOH}$ (5), $\mathrm{NaBH}_{4} / \mathrm{CF}_{3} \mathrm{COOH}$ (17) or $\mathrm{Ph}_{3} \mathrm{P}$ (18) gave the desired compound 7 in less than $5 \%$ yield, and starting material was recovered inalterated in $80-90 \%$. Whereas the reduction of 4 with the complex hydride $\mathrm{LiEt}_{3} \mathrm{BH}$ (19) (entry 5) gave only traces of 7, the reduction with $\mathrm{LiAlH}_{4}$ furnished the best results. The use of a large excess of $\mathrm{LiAlH}_{4}$ (entries 6 and 7) induced the formation of degradation products and difficulties in the isolation of the reduced product. The best conditions were obtained when 6 equivalents of $\mathrm{LiAlH}_{4}$ in ether at room temperature were used (entry 10)

Table 1. Reduction of compound 4

\begin{tabular}{|c|c|c|c|c|c|}
\hline Entry & Reducing agent (equivalents) & Solvent & $\begin{array}{l}\text { Temperature } \\
\left({ }^{\circ} \mathrm{C}\right)\end{array}$ & Yield & $\begin{array}{l}\text { Starting } \\
\text { material }^{\mathrm{a}}\end{array}$ \\
\hline 1 & $\mathrm{Fe}_{2}(\mathrm{CO})_{9}(1,2)$ & benzene & $50-100$ & $<5 \%$ & $>90 \%$ \\
\hline 2 & $\mathrm{NaBH}_{4} / \mathrm{NaOH}(10,6)$ & THF & reflux & $<5 \%$ & $>90 \%$ \\
\hline 3 & $\mathrm{NaBH}_{4} / \mathrm{CF}_{3} \mathrm{COOH}(4,5)$ & THF & $0-5$ & - & $\sim 80 \%$ \\
\hline 4 & $\mathrm{Ph}_{3} \mathrm{P}(1,1)$ & $\mathrm{CH}_{3} \mathrm{CN}$ & reflux & $<5 \%$ & $\sim 86 \%$ \\
\hline 5 & $\mathrm{Li}(\mathrm{Et})_{3} \mathrm{BH}(2,2)$ & THF & $0-5$ & $<5 \%$ & $-^{*}$ \\
\hline 6 & $\mathrm{LiAlH}_{4}$ (13) & THF & r.t. & $15 \% \mathrm{~b}$ & \\
\hline 7 & $\mathrm{LiAlH}_{4}(9)$ & THF & r.t. & $37 \% \mathrm{~b}$ & - \\
\hline 8 & $\mathrm{LiAlH}_{4}(4)$ & THF & r.t. & $28 \% \mathrm{~b}$ & $-^{*}$ \\
\hline 9 & $\mathrm{LiAlH}_{4}(4)$ & ether & r.t. & $52 \% \mathrm{~b}$ & $14 \%$ \\
\hline 10 & $\mathrm{LiAlH}_{4}(6)$ & ether & r.t. & $59 \% \mathrm{~b}$ & $-^{*}$ \\
\hline
\end{tabular}

${ }^{a}$ Calculated by $\mathrm{H}^{1}$ NMR. ${ }^{*}$ Degradation products. ${ }^{-P}$ Purified compound by chromatography on silica gel, using a mixture of ethyl acetate / hexane as the eluent.

The preparation of 7 in the literature involves a multi-steps synthesis (20). In this work we have demonstrated that a Diels-Alder cycloaddition using the commercially available 3-bromopyridine is a short and a good way for the synthesis of heterocyclic systems with a pyridine ring.

Conversion of other dienes to the polycyclic systems is now under investigation and will be the subject of a future report. 
Purity of the products was checked by TLC, $\mathrm{H}^{1}$ NMR and $\mathrm{C}^{13}$ NMR, and these compounds gave satisfactory spectral data and MS spectra (21).

Experimental Procedure for the Preparation of Diene-Aryne Cycloadducts: To a stirred solution of 3bromopyridine $(0.43 \mathrm{~mL}, 4.4 \mathrm{mmol})$ in dry THF $(1 \mathrm{~mL})$, under argon and cooled at a temperature below $-15^{\circ} \mathrm{C}$, was added dropwise a $1 \mathrm{M}$ solution of $\left(\mathrm{Me}_{3} \mathrm{Si}\right)_{2} \mathrm{NLi}$ in THF $(3.3 \mathrm{~mL}, 3.3 \mathrm{mmol})$, followed by a solution of 1,3diphenylisobenzofuran $(600 \mathrm{mg}, 2.2 \mathrm{mmol})$ in dry THF $(6 \mathrm{~mL})$. The mixture was allowed to warm to room temperature and then was heated to reflux of THF for $20 \mathrm{~h}$. It was then added $0.1 \mathrm{~N} \mathrm{HCl}(8 \mathrm{~mL})$ and water $(10$ $\mathrm{mL})$; the layers were separated and the aqueous phase was extracted with ether $(3 \mathrm{x} 40 \mathrm{~mL})$ and $\mathrm{CH}_{2} \mathrm{Cl}_{2}(2 \times$ $40 \mathrm{~mL}$ ). The combined organic layers were dried over $\mathrm{Na}_{2} \mathrm{SO}_{4}$, and vacuum evaporated to give a dark oil. Purification by chromatography (silica gel, 25:75 EtOAc / hexane) afforded $496 \mathrm{mg}$ (64\%) of pure 4 as a white solid, mp $188-190^{\circ} \mathrm{C}$ (ether / EtOAc).

\section{Acknowledgments}

The financial support of the CIRIT, Generalitat de Catalunya (QFN-4312) is gratefully acknowledged.

\section{References and Notes}

(1) K.W.Bentley, Nat. Prod. Rep. 10, 429 (1993)

(2) a) G.W.Gribble, Adv. Heterocycl. Nat. Prod. 1, 43 (1990). b) I. Antonini and S. Mortelli J. Heterocycl. Chem. 29, 471 (1992)

(3) B.A. Keay, H.P. Plaumann, D. Rajapaksa and R. Rodrigo, Can. J. Chem. 61, 1987 (1983)

(4) D.A. Davis and G.W Gribble, Tetrahedron Lett. 31, 1081 (1990)

(5) G.W. Gribble, M.G. Saulnier, M.P. Sibi and J.A. Obaza-Nutaitis, J. Org. Chem. 49, 4518 (4518)

(6) G.W. Gribble and M.G. Saulnier, Heterocycles 35, 151 (1993)

(7) T. Kauffmann and F.P. Boettcher, Chem. Ber. 95, 949 (1962)

(8) F. Marsais, M. Mallet, G. Queguiner and P. Pastour, Comp. Rend. 275, 1535 (1972) 
(9) P.S. Anderson, M.E. Christy, C.D. Colton, W. Halczenko, G.S. Ponticello and K.L. Shepard, J. Org. Chem. 44, 1519 (1979)

(10) G.W. Fleet and I. Fleming, J. Chem. Soc. Chem. Commun. 1758 (1969)

(11) C. May and J. Moody, J. Chem. Soc. Chem. Commun. 926 (1984)

(12) D.J. Pollart and B. Rickborn, J. Org. Chem. 52, 792 (1987)

(13) M. Tsukazaki and V. Snieckus, Heterocycles 33, 533 (1992)

(14) S.L. Crump, J. Netka and B. Rickborn, J. Org. Chem. 50, 2746 (1985)

(15) N. Ruiz, Ph.D. Thesis, Universite d'Orleans, France (1995).

(16) D.J. Pollart and B. Rickborn, J. Org. Chem. 51, 3155 (1986)

(17) G.W. Gribble, W.J. Kelly and M.P. Sibi, Synthesis 1, 143 (1982)

(18) C.D. Weis, J. Org. Chem. 27, 3520 (1962)

(19) S.P. Forsey, D. Rajapaksa, N.O. Taylor and R. Rodrigo, J. Org. Chem. 54, 18 (1989)

(20) F. Eiden and B. Wünsch, Arch. Pharm. (Weinheim) 319, 886.(1986)

(21) Significative spectroscopic data for the compounds 4, 5, 6 and 7 [the ${ }^{1} \mathrm{H}$ and $\mathrm{C}^{13}$ NMR spectra were recorded on a Varian Gemini 200 or 300 spectrometer with tetramethylsylane as internal standard and using $\mathrm{CDCl}_{3}$ as solvent; chemical shifts are given in $\delta$ (ppm) and the coupling constants $(\mathrm{J})$ are measured in $\mathrm{Hz}]$. MS spectra were recorded on a Hewlett-Packard $5988 \mathrm{~A}$.

4: ${ }^{1} \mathrm{H}$ NMR $\left(300 \mathrm{MHz}, \mathrm{CDCl}_{3}\right) \delta 7.07(\mathrm{~m}, 2 \mathrm{H}), 7.35(\mathrm{~m}, 3 \mathrm{H}), 7.52(\mathrm{~m}, 2 \mathrm{H}), 7.61(\mathrm{~m}, 4 \mathrm{H}), 7.90(\mathrm{dd}$, $\mathrm{J}=8.6 \mathrm{~Hz}, 4 \mathrm{H}), 8.36(\mathrm{~d}, \mathrm{~J}=4.7 \mathrm{~Hz}, 1 \mathrm{H}), 8.60(\mathrm{~s}, 1 \mathrm{H})$.

$\mathrm{m} / \mathrm{z} 347(100 \%), 105(75 \%)$.

5: ${ }^{1} \mathrm{H}$ NMR $\left(200 \mathrm{MHz}, \mathrm{CDCl}_{3}\right) \delta 1.82(\mathrm{~s}, 3 \mathrm{H}), 1.87(\mathrm{~s}, 3 \mathrm{H}), 6.67(\mathrm{~m}, 2 \mathrm{H}), 6.82(\mathrm{~m}, 2 \mathrm{H}), 7.19(\mathrm{~d}$, $\mathrm{J}=4.4 \mathrm{~Hz}, 1 \mathrm{H}), 8.40(\mathrm{~d}, \mathrm{~J}=4.4 \mathrm{~Hz}, 1 \mathrm{H}), 8.41(\mathrm{~s}, 1 \mathrm{H})$.

6: ${ }^{1} \mathrm{H}$ NMR $\left(300 \mathrm{MHz}, \mathrm{CDCl}_{3}\right) \delta 1.58(\mathrm{~s}, 3 \mathrm{H}), 1.59(\mathrm{~s}, 3 \mathrm{H}), 1.87(\mathrm{~s}, 3 \mathrm{H}), 1.91(\mathrm{~s}, 3 \mathrm{H}), 6.61(\mathrm{~m}, 4 \mathrm{H})$, $6.78(\mathrm{~m}, 2 \mathrm{H}), 6.89\left(\mathrm{dd}, \mathrm{J}_{1}=3.7 \mathrm{~Hz}, \mathrm{~J}_{2}=6 \mathrm{~Hz}, 2 \mathrm{H}\right), 7.12\left(\mathrm{dd}, \mathrm{J}_{1}=0.8 \mathrm{~Hz}, \mathrm{~J}_{2}=4,7 \mathrm{~Hz}, 1 \mathrm{H}\right), 8.33(\mathrm{~d}, \mathrm{~J}=4.8$ $\mathrm{Hz}, 1 \mathrm{H}), 8.42(\mathrm{~s}, 1 \mathrm{H})$.

$\mathrm{m} / \mathrm{z} 481(3 \%), 279(100 \%), 202(27 \%)$.

7: ${ }^{1} \mathrm{H}$ NMR $\left(200 \mathrm{MHz}, \mathrm{CDCl}_{3}\right) \delta 7.50(\mathrm{~m}, 8 \mathrm{H}), 7.56(\mathrm{~m}, 5 \mathrm{H}), 7.80\left(\mathrm{dt}, \mathrm{J}_{1}=7.6 \mathrm{~Hz}, \mathrm{~J}_{2}=6.6 \mathrm{~Hz}, 2 \mathrm{H}\right)$, $8.31(\mathrm{~d}, \mathrm{~J}=6.2 \mathrm{~Hz}, 1 \mathrm{H}), 9.18(\mathrm{~s}, 1 \mathrm{H})$.

${ }^{13} \mathrm{C}$ NMR $\left(50.4 \mathrm{MHz}, \mathrm{CDCl}_{3}\right) \delta 118.4(\mathrm{CH}), 124.6(\mathrm{C}), 125.7(\mathrm{CH}), 126.8(\mathrm{CH}), 127.0(\mathrm{CH}), 127.4$ $(\mathrm{CH}), 127.9(\mathrm{CH}), 128.1(\mathrm{CH}), 128.4(\mathrm{CH}), 128.5(\mathrm{CH}), 130.3(\mathrm{C}), 130.5(\mathrm{C}), 131.1(\mathrm{CH}), 131.2$ $(\mathrm{CH}), 132.3(\mathrm{C}), 136.0(\mathrm{C}), 136.7(\mathrm{C}), 137.4(\mathrm{C}), 139.3(\mathrm{C}), 140.2(\mathrm{CH}), 153.6(\mathrm{CH})$. $\mathrm{m} / \mathrm{z} 331(100 \%), 254(15 \%)$.

Received November 2, 1995 
